\title{
Outcome for West Syndrome Following Surgical Treatment
}

\author{
Basim M. Uthman, *S. A. Reid, B. J. Wilder, $†$ M. R. Andriola, and \\ \$Ahmad A. Beydoun
}

Departments of Neurology and ${ }^{*}$ Neurosurgery, VA Medical Center, and University of Florida; $\dagger$ Department of Neurology, School of Medicine, State University of Stony Brook, Stony Brook, New York; and $\ddagger$ Department of Neurology, University of Michigan Medical School, Ann Arbor, Michigan, U.S.A.

\begin{abstract}
Summary: We report the case of an 18-month-old child with infantile spasms and a hypsarrhythmic electroencephalogram (EEG) pattern associated with a porencephalic cyst. Surgical removal of the cyst and its surrounding tissue was performed following failure of medical therapy. Postoperatively, the patient has been free of infantile spasms for 12 months and the EEG has normalized. He
\end{abstract}

has been maintained on the same preoperative antiepileptic medications. This case suggests that surgical treatment is helpful in selected patients with infantile spasms and focal CNS lesions. Key Words: West syndromeInfantile spasms-Hypsarrhythmia-NeurosurgeryElectroencephalography.
Infantile spasms, when associated with neurological deficits or due to a known cause, are usually difficult to treat and have an overall poor prognosis. Although many etiologies have been reported, they have rarely been associated with treatable structural lesions of the brain.

We report a child with infantile spasms, a hypsarrhythmic electroencephalogram (EEG) pattern, and a unilateral porencephalic cyst. The patient failed medical therapy. Surgical removal of the cyst and its surrounding tissue was performed and he became seizure free, except for rare myoclonic jerks upon awakening. The EEG has become normal.

\section{CASE PRESENTATION}

The boy is the product of an uneventful full-term pregnancy, delivered by Cesarean section because of prolonged labor and failure to progress. His mother did not notice any developmental abnormalities. He was first evaluated at 4 months of age for infantile spasms that occurred in clusters several

Received April 1990; revision accepted August 1990.

Address correspondence and reprint requests to Dr. B. M. Uthman at Neurology Service (127), Veterans Affairs Medical Center, Gainesville, FL 32608, U.S.A. times daily. Each cluster lasted $20-30 \mathrm{~min}$. No focal seizures were reported. His neurologic examination revealed a left hemiparesis and hypertonia as well as a left visual field deficit. Computed tomography (CT) of the brain showed an area of encephalomalacia in the right parietotemporal area. His EEG revealed a hypsarrhythmic pattern that did not respond to pyridoxine. Metabolic studies, toxoplasma, rubella, cytomegalovirus, and herpes titers, and cerebrospinal fluid examination were normal. He was given a course of adrenocorticotropin $(\mathrm{ACTH})$ that resulted in a transient cessation of spasms for the next 3 months. At 8 months of age, 7 weeks following discontinuation of ACTH treatment, he developed episodes of unexplained staring and intense crying that were controlled by clonazepam (CZP), $0.5 \mathrm{mg}$, b.i.d. At 10 months of age, the infantile spasms recurred. They consisted of a brief tonic extension of both arms and generalized stiffening of the body followed by tonic elevation of both legs and deviation of the eyes and head to the left. He also developed left focal tonic seizures that lasted 10-15 s. CZP was increased to toxicity; addition of carbamazepine (CBZ), valproate (VPA), and phenytoin (PHT) failed to control his seizures. At 17 months of age, he was readmitted to the hospital because of an increase in frequency of spasms as well as development of generalized tonic-clonic 
seizures. His neurologic examination was unchanged. A magnetic resonance imaging brain scan confirmed the results of the brain CT without evidence of additional abnormalities (Fig. 1). Repeat EEGs showed a typical hypsarrhythmic pattern as well as asymmetric hypsarrhythmia with predominant epileptiform activity over the right parietotemporal area. At 18 months of age, because of persistent seizures refractory to medical treatment, the cyst and surrounding tissue were removed surgically. This "uncapping procedure" was previously described by Palm et al. (1988). An EEG recorded 1 day prior to surgery revealed hypsarrhythmia with multiple electrodecremental patterns associated with tonic deviation of the head to either side, more commonly to the left (Fig. 2). Pathologic examination of the resected specimens showed features consistent with gliosis and an encephaloclastic porencephalic cyst. Postoperatively, the child did well, showing gradual improvement in the use of his paretic left upper and lower extremities. Except for rare myoclonic jerks upon awakening, no seizures have been reported to date (12 months following surgery). Maintenance medications were PHT, 150 $\mathrm{mg} /$ day, and CZP, $1.25 \mathrm{mg} /$ day. EEGs performed 2 weeks and 6 months following surgery revealed a well-regulated $7-\mathrm{Hz}$ activity over the left occipital region, with slower low-voltage activity over most of the right hemisphere. Intermittent spikes were

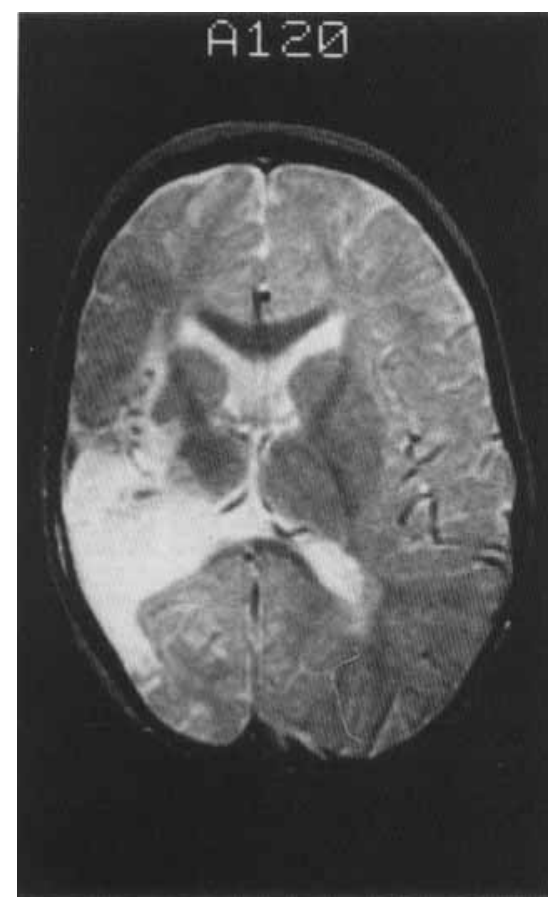

FIG. 1. Axial cut of a T2-weighted-head MRI through the genu and splenium of the corpus callosum showing the right parietotemporal porencephalic cyst. seen over the right temporal area, although much less frequently than in preoperative records (Fig. 3).

\section{DISCUSSION}

Infantile spasms, an age-specific epileptic syndrome (Commission, 1989), is associated with a hypsarrhythmic pattern on the EEG in the majority of cases (Jeavons and Bower, 1974; Lacy and Penry, 1976; Kurokawa et al., 1980; Lombroso, 1983). Children with infantile spasms are divided into idiopathic and symptomatic groups. The idiopathic group consists of patients with no neurologic deficits prior to the onset of the syndrome, while the symptomatic group is composed of patients with evidence of brain damage signs and an etiology known prior to the onset of the spasms (Lombroso, 1983; Commission, 1989). Although hypoxicischemic encephalopathy occurring perinatally is the most common cause of this syndrome (Lombroso, 1983), other common etiological factors include hemorrhages, congenital defects, metabolic encephalopathies, and dysgenetic conditions (Lombroso, 1983). Idiopathic cases usually respond to medical therapy without significant sequelae, especially if treatment is started early in the course of the clinical syndrome (Lacy and Penry, 1976; Singer et al., 1980; Dreifuss, 1983; Lombroso, 1983). Treatment failures and relapses have occurred principally among the symptomatic patients (Lacy and Penry, 1976; Dreifuss, 1983).

We believe our patient is the first well-documented case of infantile spasms caused by a porencephalic cyst that was effectively treated following surgical excision of the cyst. There are a few other reported cases in which surgical intervention has been an effective treatment modality for infantile spasms caused by structural brain lesions or cranial abnormalities (Branch and Dyken, 1979; Mimaki et al., 1983; Palm et al., 1988, 1989; Riikonen, 1984; Ruggieri et al., 1989; Shields et al., 1989). Branch and Dyken (1979) reported a case of infantile spasms, hypsarrhythmia, and developmental delay in a 7-month-old infant who became normal developmentally and was seizure-free after removal of a choroid plexus papilloma. Mimaki et al. (1983) reported a case of infantile spasms, modified hypsarrhythmia, and a right temporal astrocytoma with normalization of the EEG and absence of seizures following surgical removal of the tumor. Palm et al. $(1988,1989)$ reported 17 patients with porencephalic cysts and infantile spasms, Lennox Gastaut syndrome, or other partial seizures that were treated surgically, because of failure of medical therapy, with a "very impressive improvement of the epileptic condition." Shields et al. (1989) re- 


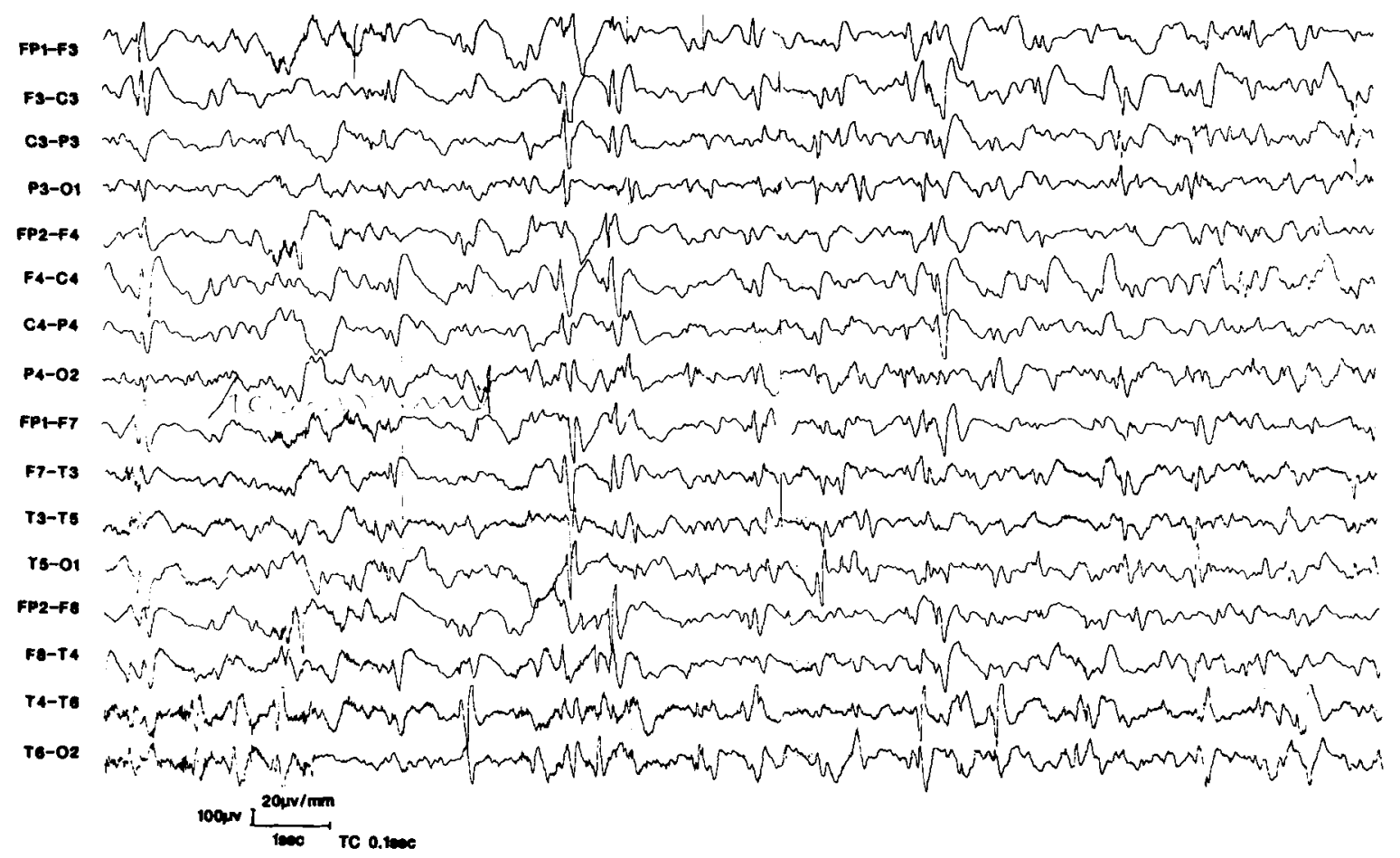

FIG. 2. EEG in sleep, recorded 1 day prior to surgery, showing a hypsarrhythmic pattern.

ported two infants with infantile spasms and focal supratentorial cortical lesions refractory to medical therapy that were controlled following surgical removal of the lesions.

In our patient, a focal structural lesion was asso- ciated with multifocal independent epileptiform foci and bilateral high-amplitude asynchronous slow waves on the EEG that normalized following surgical excision of the cyst. This indicates that infantile spasms and a hypsarrhythmic pattern on the EEG

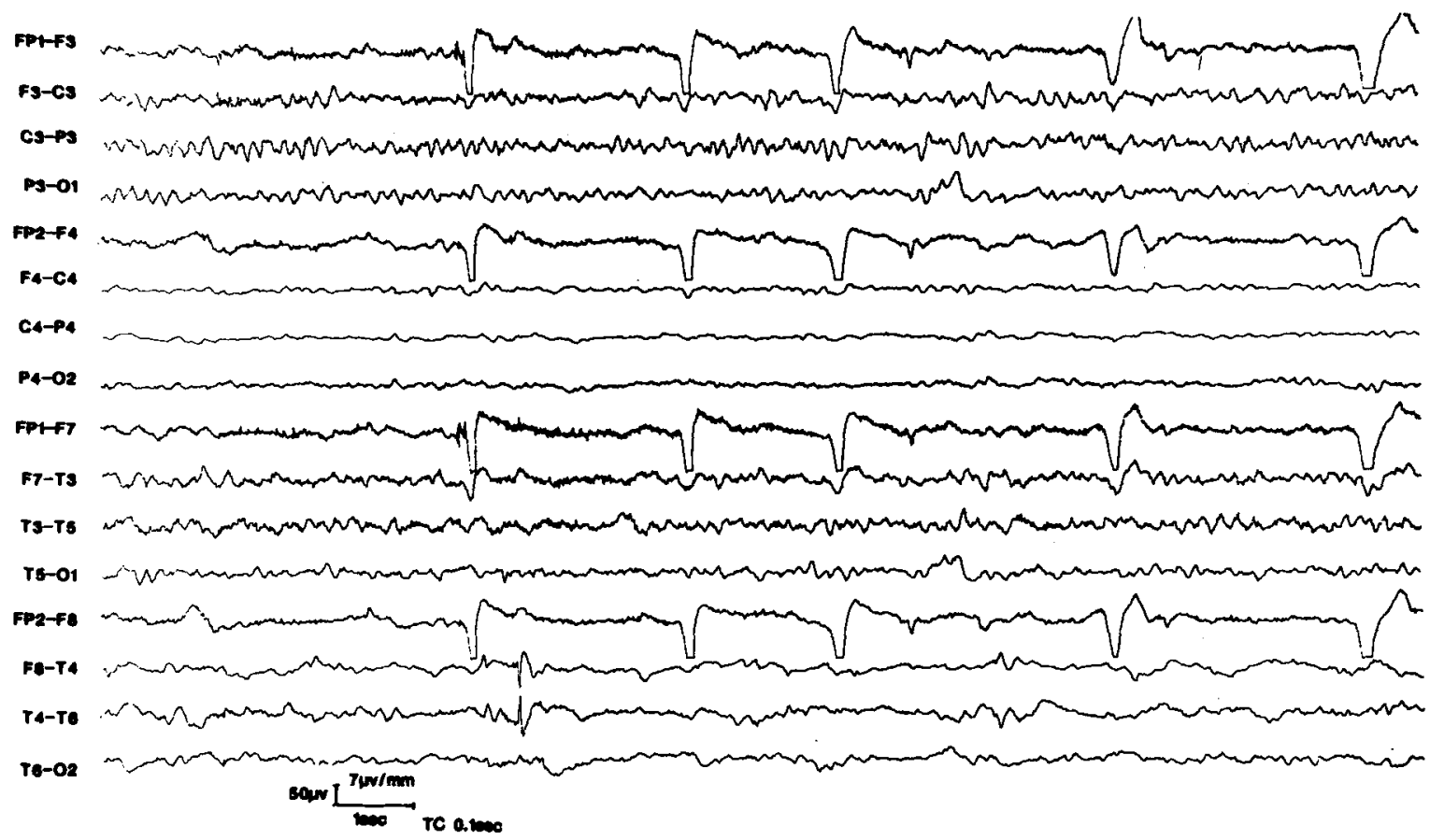

FIG. 3. EEG in wakefulness, recorded 2 weeks postoperatively, showing normal background over left hemisphere. Lowamplitude background over right hemisphere with intermittent slow waves and rare midtemporal spikes are seen. 
can be caused by a focal cerebral lesion and that the bilateral abnormalities on the EEG should not dissuade the treating physician from considering surgery in medically refractory cases.

\section{REFERENCES}

Branch CE, Dyken PR. Choroid plexus papilloma and infantile spasms. Ann Neurol 1979;5:302-4.

Commission on Classification and Terminology of the International League Against Epilepsy. Proposal for revised classification of epilepsies and epileptic syndromes. Epilepsia 1989:30:389-99.

Dreifuss FE. Infantile spasms. In: Dreifuss FE, ed. Pediatric epileptology: classification and management of seizures in the child. Littleton, Massachusetts: John Wright PSG, 1983: 97-108.

Jeavons PM, Bower BD. Infantile spasms. In: Vinken PJ, Bruyn GW, eds. The epilepsies. New York: American Elsevier, 1974:219-34 (Handbook of clinical neurology; vol. 15).

Kurokawa T, Goya N, Fukuyama Y, Suzuki M, Seki T, Ohtahara A. West syndrome and Lennox-Gastaut syndrome: a survey of natural history. Pediatrics 1980;65:81-8.

Lacy JR, Penry JK. Infantile spasms. New York: Raven Press, 1976.

Lombroso CT. A prospective study of infantile spasms: clinical and therapeutic correlations. Epilepsia 1983;24:135-58.

Mimaki T, Ono J, Yabuuchi H. Temporal lobe astrocytoma with infantile spasms. Ann Neurol 1983;14:695-6.

Palm DG, Brandt M, Korinthenberg R. West syndrome and Lennox Gastaut syndrome in children with porencephalic cysts. In: Niedermyer E, Degen R, eds. The Lennox Gastaut Syndrome. New York: Alan R. Liss, Inc., 1988:419-26.

Palm DG, Brandt $M$, Korinthenberg R. West and LennoxGastaut syndromes and other epilepsies with porencephalic cysts. Cleve Clin J Med 1989;56(suppl part 2):286-7.

Riikonen R. An unusual case of recovery from infantile spasms. Dev Med Child Neurol 1984;26:818-21.

Ruggieri V, Caraballo R, Fejerman N. Intracranial tumors and West syndrome. Pediatr Neurol 1989;5:327-9.

Shields WD, Chugani HT, Shewmon DA, Peacock W. Focal central nervous system lesions as a cause of infantile spasms. Cleve Clin J Med 1989;56(suppl part 2):291.

Singer WD, Rabe EF, Haller JS. The effect of ACTH therapy upon infantile spasms. J Pediatr 1980;96:485-9.

\section{RÉSUMÉ}

Les auteurs apportent l'observation d'un enfant de 18 mois ayant présenté des spasmes infantiles et une hypsarythmie à l'EEG, en présence d'un kyste porencéphalique. L'ablation chirurgicale du kyste et du tissu environnant a été réalisée aprés échec du traitement médical. En post-opératoire, le patient est resté libre de tout spasme infantile pendant 12 mois, et l'EEG a été normalisé. L'enfant a été maintenu sous le traitement antiépileptique antérieur à l'intervention. Ce cas suggère que le traitement chirurgical peut être utile chez les patients sélectionnés présentant des spasmes infantiles et une lésion cérébrale focalisée.

(P. Genton, Marseille)

\section{RESUMEN}

Se publica un caso de un niño de 18 meses de edad con espasmos infantiles y un patrón hipsarrítmico en el EEG asociado a un quiste porencefálico. La estirpación quirúrgica del quiste y del tejido periquístico se realizó después del fracaso de la terapéutica médica. El enfermo no ha tenido ningún tipo de espasmos infantiles durante los 12 meses postoperatorios y el EEG se ha normalizado. Durante todo este tiempo ha continuado tomando las mismas medicaciones antiepilépticas previas a la cirugía. Este caso sugiere que el tratamiento quirúrgico puede ser eficaz en enfermos seleccionados con espasmos infantiles y lesiones focales del Sistema Nervioso Central.

(A. Portera-Sánchez, Madrid)

\section{ZUSAMMENFASSUNG}

Wir berichten über ein 18 Monate altes Kind mit BNSAnfällen und einer Hypsarrhythmie, assoziiert mit einer porenzephalen Zyste. Die chirurgische Entfernung der Zyste und des umgebenden Gewebes geschah nach Versagen der konservativen Therapie. Postoperativ war der Patient über 12 Monate anfallsfrei und das EEG normalisierte sich. Der Patient wurde bei der präoperativen antiepileptischen Medikation belassen. Dieses Fallbeispiel legt nahe, daß eine chirurgische Behandlung bei ausgewählten Patienten mit BNS-Anfällen und fokalen Hirnläsionen sinnvoll ist.

(C. Benninger, Heidelberg) 